\title{
Admissions to intensive care unit of HIV-infected patients in the era of highly active antiretroviral therapy: etiology and prognostic factors
}

Hou-Hsien Chiang ${ }^{1}$, Chien-Ching Hung ${ }^{2}$, Chang-Min Lee ${ }^{3}$, Hsuan-Yu Chen ${ }^{4}$, Mao-Yuan Chen ${ }^{2}$, Wang-Huei Sheng ${ }^{2}$, Szu-Min Hsieh², Hsin-Yun Sun², Chao-Chi Ho ${ }^{5^{*}}$ and Chong-Jen Yu ${ }^{5}$

\begin{abstract}
Introduction: Although access to highly active antiretroviral therapy (HAART) has prolonged survival and improved life quality, HIV-infected patients with severe immunosuppression or comorbidities may develop complications that require critical care support in intensive care units (ICU). This study aimed to describe the etiology and analyze the prognostic factors of HIV-infected Taiwanese patients in the HAART era.

Methods: Medical records of all HIV-infected adults who were admitted to ICU at a university hospital in Taiwan from 2001 to 2010 were reviewed to record information on patient demographics, receipt of HAART, and reason for ICU admission. Factors associated with hospital mortality were analyzed.

Results: During the 10-year study period, there were 145 ICU admissions for 135 patients, with respiratory failure being the most common cause (44.4\%), followed by sepsis (33.3\%) and neurological disease (11.9\%). Receipt of HAART was not associated with survival. However, CD4 count was independently predictive of hospital mortality (adjusted odds ratio [AOR], per-10 cells/mm³ decrease, 1.036; 95\% confidence interval [Cl], 1.003 to 1.069). Admission diagnosis of sepsis was independently associated with hospital mortality ( $\mathrm{AOR}, 2.91 ; 95 \% \mathrm{Cl}, 1.11$ to 7.62). A hospital-to-ICU interval of more than 24 hours and serum albumin level (per 1-g/dl decrease) were associated with increased hospital mortality, but did not reach statistical significance in multivariable analysis.

Conclusions: Respiratory failure was the leading cause of ICU admissions among HIV-infected patients in Taiwan. Outcome during the ICU stay was associated with CD4 count and the diagnosis of sepsis, but was not associated with HAART in this study.
\end{abstract}

\section{Introduction}

After the introduction of highly active antiretroviral therapy (HAART), the life expectancy of HIV-infected patients has significantly increased and the incidence of illnesses associated with AIDS markedly decreased [1]. Nevertheless, HIV-related complications that may require critical care support continue to occur in HIVinfected patients who are unaware of their HIV serostatus and do not initiate HAART and appropriate antimicrobial prophylaxis, or who fail to respond to HAART with virological and immunologic failures. These

\footnotetext{
* Correspondence: ccho1203@ntu.edu.tw

${ }^{5}$ Division of Chest Medicine, Department of Internal Medicine, National Taiwan University Hospital, Chung-Shan South Road, Taipei 100, Taiwan Full list of author information is available at the end of the article
}

patients may also require critical care because of other co-morbidities such as hepatitis co-infections, alcoholism, or chronic obstructive pulmonary disease [2]. Although respiratory failure and Pneumocystis jirovecii pneumonia have declined in the HAART era compared with the pre-HAART era, they remain the most common diagnoses of HIV-infected patients who were admitted to ICUs $[3,4]$. Compared with patients in the pre-HAART era, patients in the HAART era are more likely to have life-threatening sepsis, neurologic disorders, and complications of end-stage liver disease [4-6].

Several studies have shown that the advent of HAART not only improved the survival of HIV-infected patients admitted to ICU [7-10], but also changed the etiology of admissions to the ICU whereby fewer patients were 
admitted to the ICU due to opportunistic infections [10-13]. However, the patient populations included in the studies examining the benefits of HAART are heterogeneous in exposure to HAART, durations of HAART, and timing of HAART [14-20]. The results on survival benefits of HAART are inconsistent across the reported studies in the HIV-infected patients who are already admitted to ICU.

In the era of HAART, prognostic factors of mortality for HIV-infected patients admitted to ICU do not appear to have significant changes $[8,12,14-20]$. These factors include the severity of acute illness (as assessed by Acute Physiology and Chronic Health Evaluation II (APACHE II) score, Simplified Acute Physiology Score II (SAPS II), or Sequential Organ Failure Assessment (SOFA) score), presence of organ failure (requirement of mechanical ventilator support, shock, renal failure), CD4 lymphocyte count, hospital-to-ICU interval, and serum albumin level. However, these reports mostly came from North America, Latin America, and European countries that enrolled largely white, black, and Hispanic people. It remains unknown whether HIV-infected patients in the Asia-Pacific countries who are admitted to the ICU share the same etiologies and prognostic factors.

In this study, we aimed to describe the etiologies of ICU admissions of HIV-infected patients in a university hospital in Taiwan and to examine the prognostic factors of hospital mortality in the era of HAART. The results of our study will be compared with those of other published studies in HIV-infected patients admitted to ICUs in the HAART era.

\section{Materials and methods Study population}

This retrospective cohort study was conducted in the National Taiwan University Hospital, the largest designated hospital to provide inpatient and outpatient HIV care in Taiwan, to enroll all HIV-infected patients aged 18 years or greater who were admitted to the medical and surgical ICU from 1 January, 2001 to 28 February, 2010. The Research Ethics Committee of the hospital approved the study protocol and waived the need for informed consent.

HAART was introduced into Taiwan in April 1997 and all HIV-infected patients have free-of-charge access to antiretroviral therapy according to local treatment guidelines and inpatient and outpatient care that is related to HIV infection at designated hospitals and clinics around Taiwan. The medical costs, including antiretroviral therapy and laboratory investigations such as determinations of CD4 lymphocyte count and plasma HIV RNA load, are totally reimbursed by the National Health Insurance and a special budget of Taiwan Centers for Disease Control. Regarding the end-of-life decisions, patients and/or their family can choose not to receive mechanical ventilation, inotropic agents, cardiopulmonary-cerebral resuscitation, or electric shock. However, when patients are in critical illness, we do not withdraw mechanical ventilation or inotropic agents that are already applied on them.

\section{Data collection and definitions}

We used a standardized case collection form to record information on demographics, clinical history, risk factors for HIV infection, HAART, and CD4 lymphocyte count and plasma HIV RNA load that were available within one month of ICU admission. If patients were readmitted to the ICU during the same hospitalization, only the data from the first admission were included for analysis of admission diagnoses and mortality predictors.

Prior HAART use was defined as receipt of at least two classes of antiretroviral drugs at the time of hospital admission [21]. Laboratory data within three days of ICU admission (usually within 24 hours) were recorded. Organ failure status (requirement of mechanical ventilator support, renal replacement, or shock) and APACHE II scores on ICU admission were also recorded [22]. Shock status was considered if use of vasopressors was longer than 24 hours. The primary outcome was hospital mortality.

Diagnosis of $P$. jirovecii pneumonia was based on identification of Pneumocystis in the sputum, bronchoalveolar-lavage fluid, or transbronchoscopic or surgical lung biopsy $[23,24]$. For patients admitted to ICU with interstitial pneumonitis that was diagnosed based on radiographic presentations of ground-glass opacities by high-resolution computed tomography (HRCT), but without isolated $P$. jirovecii, they were also classified as having interstitial pneumonitis of unknown etiology.

\section{Statistical analysis}

Clinical characteristics are reported as medians and interquartile range (IQR) or numbers and percentages. Multivariable logistic regression analysis was used to evaluate patient characteristics associated with hospital mortality. Variables with $P$ values less than 0.20 in the univariable analyses were entered into a multivariable logistic regression model with non-stepwise method. Final model fit was assessed using the Hosmer-Lemeshow and specification tests. SPSS version 17.0 (SPSS Inc., Chicago, IL, USA) was performed for statistic analyses. $P$ values less than 0.05 were considered statistically significant.

\section{Results}

\section{Demographic and clinical characteristics}

During the 10-year-study period, there were $145 \mathrm{ICU}$ admissions for 135 patients. Ten patients were admitted 
to ICU twice during the same hospitalization. The majority of the ICU cohort were men $(91.1 \%)$ and Taiwanese $(98.5 \%)$ (Table 1$)$. The median age was 39 years. Sexual contact was the main risk factor for HIV transmission. The median interval between first HIV diagnosis to ICU admission was 1.23 months (IQR, 0-36 months), and 60 patients (44.4\%) were newly diagnosed as having HIV infection on admission. The median plasma HIV viral load that was available for 121 patients was 217,000 copies/ml (IQR, 34,500-631,500 copies/ml), and the median $\mathrm{CD} 4$ lymphocyte count that was available for 129 patients was 30 cells $/ \mathrm{mm}^{3}$ (IQR, 13103 cells $\left./ \mathrm{mm}^{3}\right)$. Overall, 82 patients $(60.7 \%)$ received HAART during the ICU stay: 49 patients (36.3\%) receiving prior HAART at hospital admission, and 12 patients (8.9\%) initiating HAART during the ICU stay.

With respect to the organ failure status, 106 patients (78.5\%) needed mechanical ventilator support, 49 patients (36.3\%) needed vasopressors for more than 24 hours after admission to ICU, and 11 patients $(8.1 \%)$ received renal replacement therapy during the ICU stay. The median serum albumin level on ICU admission that

Table 1 Clinical characteristics of 135 HIV-infected patients who were admitted to the ICUs at the National Taiwan University Hospital from 2001 to 2010

\begin{tabular}{|c|c|}
\hline Characteristics & 135 patients \\
\hline Median age (years) & $39(31-50)$ \\
\hline Male sex & $123(91.1)$ \\
\hline \multicolumn{2}{|l|}{ Race/ethnicity } \\
\hline Taiwanese & $133(98.5)$ \\
\hline other Asians & $2(1.5)$ \\
\hline \multicolumn{2}{|l|}{ HIV risk factor } \\
\hline Homosexual & $53(39.3)$ \\
\hline Bisexual & $7(5.2)$ \\
\hline Injecting drug use & $16(11.9)$ \\
\hline Transfusion-related & $3(2.2)$ \\
\hline Heterosexual/other/unknown & $56(41.5)$ \\
\hline \multicolumn{2}{|l|}{ HIV-related characteristics } \\
\hline Newly diagnosed HIV infection & $60(44.4)$ \\
\hline Time since HIV diagnosis (month) & $1.23(0-36)$ \\
\hline Time since AIDS diagnosis (month) & $0.73(0-26)$ \\
\hline Prior HAART at hospital admission & $49(36.3)$ \\
\hline Duration of HAART for patients on prior HAART (month) ${ }^{a}$ & $13(6-48)$ \\
\hline HAART initiated during ICU stay & $12(8.9)$ \\
\hline HAART use in ICU & $82(60.7)$ \\
\hline HIV viral load $(\text { copies } / \mathrm{ml})^{b}$ & $217,000(34,500-631,500)$ \\
\hline CD4 lymphocyte count $\left(\text { cells } / \mathrm{mm}^{3}\right)^{c}$ & $30(13-103)$ \\
\hline \multicolumn{2}{|l|}{ Organ failure status } \\
\hline Mechanical ventilator use & $106(78.5)$ \\
\hline Shock (use of vasopressors $>24$ hours) & $49(36.3)$ \\
\hline Renal replacement therapy & $11(8.1)$ \\
\hline Time from hospitalization to ICU admission (days) & $2(0-9.0)$ \\
\hline \multicolumn{2}{|l|}{ Laboratory data } \\
\hline Albumin $(\mathrm{g} / \mathrm{dL})^{d}$ & $2.83(2.40-3.40)$ \\
\hline $\mathrm{LDH}\left(\right.$ units/L) ${ }^{e}$ & $966.5(686.5-1446.25)$ \\
\hline APACHE II score & $19(15-25)$ \\
\hline in-ICU mortality & $50(37.0)$ \\
\hline in-hospital mortality & $66(48.9)$ \\
\hline
\end{tabular}

Values are given as median (interquartile) or number (\%), unless otherwise indicated.

${ }^{a}$ Data were available for 49 patients with prior HAART at hospital admission.

${ }^{b}$ Data were available for 121 patients.

'Data were available for 129 patients.

${ }^{d}$ Data were available for 127 patients.

${ }^{e}$ Data were available for 114 patients.

APACHE II, Acute Physiology and Chronic Health Evaluation II; HAART, highly active antiretroviral therapy; LDH, lactate dehydrogenase. 
was available for 127 patients was $2.83 \mathrm{~g} / \mathrm{dl}$ (IQR, 2.40$3.40 \mathrm{~g} / \mathrm{dl}$ ). The median APACHE II score on ICU admission was 19 (IQR, 15-25). ICU mortality was 50 of 135 patients (37.0\%), and hospital mortality was 66 of 135 patients $(48.9 \%)$.

\section{Diagnoses of ICU admissions}

Respiratory failure was the cause for ICU admissions in 60 of all 135 patients (44.4\%; Table 2). Among the patients with respiratory failure, interstitial pneumonitis with ground-glass opacity was the most common cause of respiratory failure (51 patients, $37.8 \%)$. P. jirovecii pneumonia was confirmed in 11 patients $(8.1 \%)$, and pathology-proven cytomegalovirus (CMV) pneumonitis occurred in nine patients (6.7\%). Sepsis (including bacterial pneumonia) was diagnosed in 45 patients (33.3\%), followed by neurological disease (16 patients, $11.9 \%)$ and postoperative care (five patients, 3.7\%).

\section{Predictors of in-ICU and in-hospital mortality}

In the univariable analysis of hospital mortality, there was no difference between survivors and non-survivors with respect to prior HAART, HAART initiated during the ICU stay, or HAART use during the stay in the ICU (Table 3). The factors associated with hospital mortality in univariable analysis were CD4 lymphocyte count (per 10 cells $/ \mathrm{mm}^{3}$ decrease), admission diagnosis of sepsis, the interval between hospitalization and ICU transfer of more than 24 hours, and serum albumin level (per $1 \mathrm{~g} /$ $\mathrm{dl}$ decrease; Table 3). In multivariable logistic regression analysis, the independent predictors of hospital mortality

Table 2 Diagnoses of 135 HIV-infected patients admitted to ICU

\begin{tabular}{ll}
\hline Admission diagnosis & $\begin{array}{l}\text { Number (\%) of } \\
\text { admissions }\end{array}$ \\
\hline $\begin{array}{l}\text { Respiratory failure } \\
\quad \text { Interstitial pneumonitis with ground glass }\end{array}$ & $60(44.4)$ \\
$\quad$ opacity & $11(8.1)$ \\
$\quad$ Pneumocystosis & $9(6.7)$ \\
$\quad$ CMV (pathology-proven) & $35(25.9)$ \\
$\quad$ Interstitial pneumonitis of unknown & \\
$\quad$ etiology & $11(8.1)$ \\
$\quad$ Others & $45(33.3)$ \\
Sepsis (including bacteria pneumonia) & $16(11.9)$ \\
Neurological disease & $5(3.7)$ \\
Postoperative care & $3(2.2)$ \\
Trauma & $2(1.5)$ \\
Metabolic disturbance & $2(1.5)$ \\
Cardiac disease & $2(1.5)$ \\
Gastrointestinal bleeding & $1(0.7)$ \\
Drug overdose & $3(2.2)$ \\
Miscellaneous &
\end{tabular}

CMV, cytomegalovirus. were CD4 lymphocyte count (per 10 cells $/ \mathrm{mm}^{3}$ decrease) (adjusted odds ratio (AOR), 1.036; 95\% confidence interval $(\mathrm{CI}), 1.003-1.069 ; P=0.033)$, and diagnosis of sepsis (AOR, 2.91; 95\% CI, 1.11-7.62; $P=0.029$ ). Kaplan-Meier survival curves for 129 patients stratified by sepsis and CD4 count less than 50 cells $/ \mathrm{mm}^{3}$ (six patients without available CD4 counts were excluded) are showed in Figure 1. Log-rank testing was significant difference between the four groups $(P=0.003)$.

\section{Discussion}

This study is the first cohort study to analyze the etiologies of ICU admissions and to investigate the predictors of mortality in HIV-infected patients in the Asia-Pacific region. In the current study, respiratory failure was the leading cause of ICU admissions among HIV-infected patients, followed by sepsis and neurological disease. CD4 lymphocyte count and admission diagnosis of sepsis are two independent predictors of hospital mortality in multivariable analysis.

The causes of ICU admissions observed in our study are not different from those observed in other studies that were conducted in North America, Latin America, and European countries [8,10,14-16,18-20,25] (Table 4). However, the percentage of each etiology differs between our study and others. In our study, $8.1 \%$ of the patients admitted to ICU had diagnoses of $P$. jirovecii pneumonia, and $25.9 \%$ of the patients were classified as interstitial pneumonitis with unknown etiology, which might be probable cases of $P$. jirovecii pneumonia when the radiographic findings and clinical response to specific anti-pneumocystosis therapy were taken into consideration. Taking definite and probable cases of pneumocystosis together, it might comprise $34.0 \%$ of the patients, which is more than those of other reports [8,10,14-16,18-20,25] (Table 4). In addition, the percentage of newly diagnosed HIV infection on admission (46.2\%) is higher, and the median CD4 count (30 cells/ $\mathrm{mm}^{3}$ ) is lower than those in other studies (Table 4). The above observations may be because our hospital is a referral hospital and the majority of patients admitted to this hospital were severely immunocompromised and were not on HAART $[26,27]$. In our study, $63.7 \%$ of the patients did not receive HAART before hospital admissions.

In this study, we identified two independent predictors of hospital mortality in multivariable analysis: CD4 lymphocyte count and admission diagnosis of sepsis. Low CD4 lymphocyte count is associated with suppressed cellular immunity, and its association with increased mortality has also been demonstrated in prior studies $[15,20]$.

The association between sepsis and higher rate of mortality in the critically ill HIV-AIDS population has 
Table 3 Univariable and multivariable analyses of characteristics associated with hospital mortality

\begin{tabular}{|c|c|c|c|c|}
\hline \multirow[t]{2}{*}{ Characteristics } & \multicolumn{2}{|c|}{ Univariable analysis } & \multicolumn{2}{|c|}{ Multivariable analysis } \\
\hline & $\begin{array}{c}\text { Odds ratio } \\
(95 \% \mathrm{Cl})\end{array}$ & $\begin{array}{c}P \\
\text { value }\end{array}$ & $\begin{array}{l}\text { Odds ratio } \\
(95 \% \mathrm{Cl})\end{array}$ & $\begin{array}{c}P \\
\text { value }\end{array}$ \\
\hline Age (per 10-year increase) & $1.15(0.88-1.51)$ & 0.3 & & \\
\hline Male & $2.03(0.58-7.10)$ & 0.27 & & \\
\hline HIV risk factor & & 0.8 & & \\
\hline MSM & reference & & & \\
\hline Bisexual & $0.78(0.16-3.82)$ & 0.8 & & \\
\hline Injecting drug use & $0.62(0.20-1.96)$ & 0.4 & & \\
\hline Transfusion-related & $2.08(0.18-24.31)$ & 0.6 & & \\
\hline Heterosexual/other/unknown & $1.12(0.53-2.37)$ & 0.8 & & \\
\hline \multicolumn{5}{|l|}{ HIV-related characteristics } \\
\hline Newly diagnosed HIV infection & $1.56(0.79-3.08)$ & 0.205 & & \\
\hline Prior HAART at hospital admission & $0.78(0.39-1.57)$ & 0.5 & & \\
\hline HAART initiated during ICU stay & $1.05(0.32-3.44)$ & 0.9 & & \\
\hline HAART use in ICU & $1.12(0.56-2.24)$ & 0.7 & & \\
\hline HIV viral load (per 1-log copies/ml increase) ${ }^{a}$ & $1.025(0.83-1.26)$ & 0.8 & & \\
\hline CD4 lymphocyte count (per 10-cells $/ \mathrm{mm}^{3}$ decrease) $)^{b}$ & $1.033(1.004-1.063)$ & 0.027 & $1.036(1.003-1.069)$ & 0.033 \\
\hline \multicolumn{5}{|l|}{ Admission diagnosis } \\
\hline Respiratory failure & $0.99(0.50-1.95)$ & 1.0 & & \\
\hline Interstitial pneumonitis with ground glass opacity & $0.78(0.39-1.57)$ & 0.5 & & \\
\hline Sepsis (including bacterial pneumonia) & $2.25(1.08-4.69)$ & 0.03 & $2.91(1.11-7.62)$ & 0.029 \\
\hline Hospitalization to ICU admission $>24$ hours & $2.72(1.23-6.01)$ & 0.013 & $2.21(0.90-5.47)$ & 0.085 \\
\hline Albumin (per $1 \mathrm{~g} / \mathrm{dl}$ decrease) ${ }^{c}$ & $1.69(1.04-2.74)$ & 0.034 & $1.31(0.74-2.34)$ & 0.36 \\
\hline
\end{tabular}

The goodness of fit (Hossmer-Lemeshow Chisquare $P$ value) was 0.619. 14 patients were not included in the multivariable model because of missing data.

${ }^{a}$ Data were available for $121 \mathrm{ICU}$ admissions.

${ }^{b}$ Data were available for 129 ICU admissions.

'Data were available for 127 ICU admissions.

$\mathrm{Cl}$, confidence interval; HAART, highly active antiretroviral therapy; MSM, men who have sex with men.

been shown in previous studies [14,15,18,19] (Table 4). Japiassú AM et al. reported that sepsis is a major determinant of 28-day and six-month mortality in HIVinfected patients admitted to ICU (adjusted hazard ratio, 3.13 and 3.35, respectively). The above study and our study both revealed that pneumonia is the most common site of infection (52\% and 55.6\%, respectively), whereas our cohort had cases of fewer primary bacteremia (15.6\%) and nosocomial infections (37\%) [19]. The screening of HIV infection and high suspicion to sepsis diagnosis could contribute to decrease mortality in critically ill HIV/AIDS patients $[19,28,29]$. The trend of relatively lower mortality for patients with interstitial pneumonitis with ground-glass opacity may be attributed to increased alertness to identification of severely immunocompromised patients who present with characteristic radiographic findings $[1,4]$.

Although early initiation of HAART has been shown to improve survival in patients with AIDS-related opportunistic infections [13], it remains debatable whether initiation of HAART improves the outcome of patients admitted to ICU owing to factors related to issues of toxicity, bioavailability, and drug-drug interactions [1].
Several studies, including ours, failed to demonstrate short-term survival benefit of HAART in those patients admitted to ICU [16-20], probably because in those patients with severely depleted CD4 counts, improvement of immunity in terms of increase of CD4 counts or function cannot be achieved after short term of HAART. Furthermore, early initiation of HAART in patients with depleted CD4 counts and opportunistic illnesses, such as tuberculosis, non-tuberculous mycobacteriosis, cryptococcosis, and Kaposi's sarcoma, is associated with increased risk of immune reconstitution inflammatory syndrome $[13,30]$, which may increase difficulties in clinical management and mortality in resource-limited settings.

Prevalence and trends of antiretroviral drug resistance mutations may also affect the treatment response to HAART [31]. In Taiwan, the frequency of HIV-1 isolates harbored one or more primary mutations associated with antiretroviral resistance to reversetranscriptase inhibitors or protease inhibitors increased significantly from $6.6 \%$ in 1999 to 2003 to $12.7 \%$ in 2004 to $2006(P=0.003)$ [32]. In our study, 49 patients had been taking HAART for a median duration of 13 


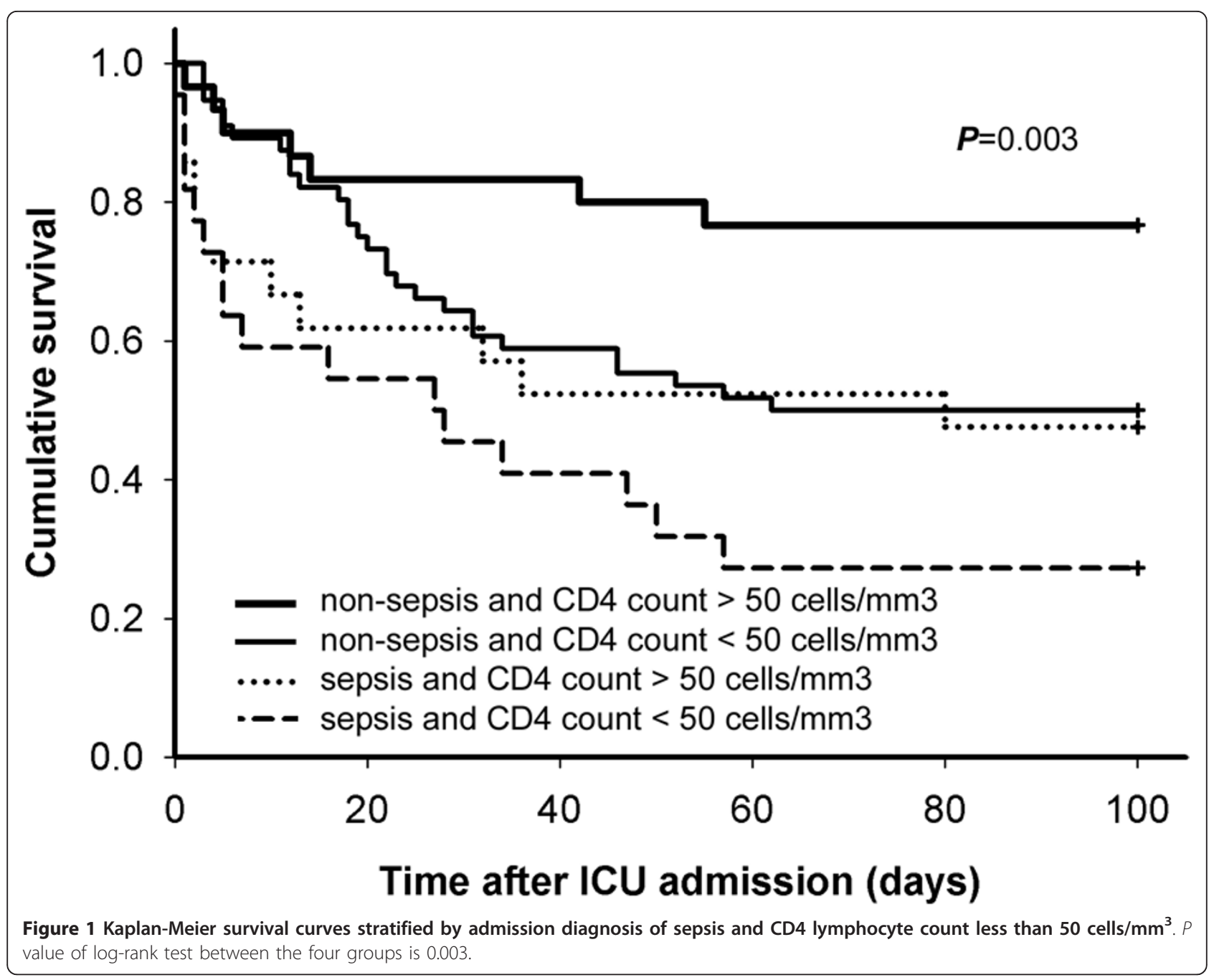

months (IQR, 6-48 months), and their median CD4 count was 67 cells $/ \mathrm{mm}^{3}$ (IQR, 16-207 cells $/ \mathrm{mm}^{3}$ ). The suboptimal treatment responses to HAART in these patients may be due to the presence of transmitted drug resistance of the HIV strains, poor adherence to antiretroviral therapy prescribed that may result in emergence of antiretroviral drug resistance mutations, and immunologic non-response [31].

Lower serum albumin level has been found to be a poor prognostic factor in the studies from San Francisco General Hospital $[8,16]$. In our study, we also found that serum albumin level less than $2.8 \mathrm{~g} / \mathrm{dl}$ is associated with hospital mortality, although it is of no statistical significance in multivariable analysis. Low serum albumin level may be the results of poor nutritional status and severe catabolism from the prolonged critical illness, which may lead to insufficient intravascular volume, hemodynamic instability, increased extravascular lung water, and therefore, increased mortality $[33,34]$.
There are several limitations in this study. First, our study is retrospective and observational in study design, which may preclude us from identifying every possible confounding factor. Second, the case number in this study remains small and prospective studies of larger case number are needed to examine the impact of HAART and other parameters on the outcomes of HIVinfected patients who require care in the ICU. Third, the majority of our patients acquired HIV through sexual contact and our findings may not be generalizable to the health care facilities that provide HIV care to a higher proportion of injecting drug users who are more likely to develop bacterial complications due to use of contaminated syringes, needles and diluent. Fourth, our findings may not be generalizable to other hospitals because the decisions of admissions to ICU in this referral hospital for HIV care depends on clinical assessment of the treating physicians and consultations with the critical care specialists, which may vary among the hospitals providing HIV care. Finally, we were not able to 
Table 4 Comparisons of studies regarding HIV-infected patients admitted to ICU in the HAART era

\begin{tabular}{|c|c|c|c|c|c|c|c|c|}
\hline $\begin{array}{l}\text { City } \\
\text { [reference] }\end{array}$ & $\begin{array}{c}\text { San Francisco } \\
{[8]}\end{array}$ & San Francisco [16] & $\begin{array}{c}\text { New York } \\
\text { [20] }\end{array}$ & $\begin{array}{l}\text { Paris } \\
{[18]}\end{array}$ & $\begin{array}{c}\text { Mexico } \\
{[14]}\end{array}$ & $\begin{array}{c}\text { São Paulo } \\
\text { [15] }\end{array}$ & $\begin{array}{c}\text { Rio de Janeiro } \\
{[19]}\end{array}$ & Taipei \\
\hline Study year & 1996-1999 & $2000-2004$ & $1997-1999$ & $1996-2005$ & $1996-2006$ & $1996-2006$ & $2006-2008$ & $2001-2010$ \\
\hline \multicolumn{9}{|l|}{$\begin{array}{l}\text { HIV-related } \\
\text { characteristics }\end{array}$} \\
\hline $\begin{array}{l}\text { Newly } \\
\text { diagnosed HIV } \\
(\%)\end{array}$ & 5.6 & - & - & $19.7^{a}$ & 26 & 38 & 28 & 44.4 \\
\hline $\begin{array}{l}\text { Median CD4 } \\
\text { count (cells/ } \\
\mathrm{mm}^{3} \text { ) }\end{array}$ & 64 & 109 & 85 & - & - & 39 & 75 & 30 \\
\hline \multicolumn{9}{|l|}{$\begin{array}{l}\text { ICU admission } \\
\text { diagnosis (\%) }\end{array}$} \\
\hline $\begin{array}{l}\text { Respiratory } \\
\text { failure (\%) }\end{array}$ & 40.7 & 42.3 & 30.0 & 58.8 & 51.0 & 33.1 & 29 & 44.4 \\
\hline $\begin{array}{l}\text { pneumocystosis } \\
(\%)\end{array}$ & 10.7 & 13.8 & - & 18.7 & - & 23.2 & - & $8.1^{b}$ \\
\hline Sepsis (\%) & 11.9 & 20.3 & 13.0 & 23.9 & 26.0 & 31.2 & 20.5 & 33.3 \\
\hline $\begin{array}{l}\text { Neurological } \\
\text { disease (\%) }\end{array}$ & 12.4 & 16.3 & 18.0 & 32 & 15.0 & 19.4 & 22.7 & 11.9 \\
\hline Others (\%) & 35.0 & 21.1 & 39.0 & - & 21.0 & 16.2 & 27.3 & 13.3 \\
\hline \multicolumn{9}{|l|}{$\begin{array}{l}\text { Mortality } \\
\text { predictors }\end{array}$} \\
\hline ART use & $\begin{array}{c}\text { No prior HAART } \\
\text { univariably increased } \\
\text { hospital mortality, } 1.8 \\
\text { (1.02-3.2), but not } \\
\text { significantly in } \\
\text { multivariable analysis }\end{array}$ & No association & No association & No association & $\begin{array}{c}\text { No prior } \\
\text { HAART } \\
\text { independently } \\
\text { increased ICU } \\
\text { mortality, } 3.33 \\
(1.43-10.0)^{c}\end{array}$ & $\begin{array}{c}\text { No ART use in } \\
\text { ICU } \\
\text { independently } \\
\text { increased 6- } \\
\text { month } \\
\text { mortality, } 2.00 \\
(1.41-2.86)\end{array}$ & No association & No association \\
\hline $\begin{array}{l}\text { CD4 count } \\
\text { (cells/mm3) }\end{array}$ & - & - & $\begin{array}{c}\text { CD4 < } 200 \text { univariably } \\
\text { increased hospital } \\
\text { mortality, } 2.24 \text { (1.16- } \\
4.31) \text {, but not } \\
\text { significantly in } \\
\text { multivariable analysis }\end{array}$ & No association & - & $\begin{array}{c}\text { CD4 < } 50 \\
\text { independently } \\
\text { increased ICU } \\
\text { mortality, } 2.10 \\
(1.17-3.76)\end{array}$ & No association & $\begin{array}{c}\text { CD4 (per 10-cells } / \mathrm{mm}^{3} \\
\text { decrease) independently } \\
\text { increased hospital mortality, } \\
1.036(1.003-1.069)\end{array}$ \\
\hline $\begin{array}{l}\text { Admission } \\
\text { diagnosis of } \\
\text { sepsis }\end{array}$ & - & $\begin{array}{l}\text { No significant } \\
\text { difference between } \\
\text { with sepsis and } \\
\text { respiratory failure }\end{array}$ & - & $\begin{array}{c}\text { Severe sepsis } \\
\text { independently } \\
\text { increased ICU } \\
\text { mortality, 3.67 } \\
(1.53-8.80)\end{array}$ & $\begin{array}{c}\text { Septic shock } \\
\text { independently } \\
\text { increased ICU } \\
\text { mortality, } 2.4 \\
(1.1-5.2)^{c}\end{array}$ & $\begin{array}{c}\text { Sepsis } \\
\text { independently } \\
\text { increased ICU } \\
\text { mortality, 3.16 } \\
(1.65-6.06)\end{array}$ & $\begin{array}{c}\text { Severe sepsis/ } \\
\text { septic shock } \\
\text { independently } \\
\text { increased 28-day } \\
\text { mortality, 3.13 } \\
(1.21-8.07)^{c}\end{array}$ & $\begin{array}{c}\text { Sepsis independently } \\
\text { increased hospital mortality, } \\
2.91 \text { (1.11-7.62) }\end{array}$ \\
\hline
\end{tabular}


Table 4 Comparisons of studies regarding HIV-infected patients admitted to ICU in the HAART era (Continued)

\begin{tabular}{|c|c|c|c|c|c|c|c|c|}
\hline $\begin{array}{l}\text { Hospital-to-ICU } \\
\text { interval }\end{array}$ & - & - & - & $\begin{array}{l}\text { Delayed ICU } \\
\text { admission } \\
\text { independently } \\
\text { increased ICU } \\
\text { mortality, 3.04 } \\
\quad(1.29-7.71)\end{array}$ & - & - & - & $\begin{array}{c}\text { Hospital-to-ICU interval > } 24 \\
\text { hours univariably increased } \\
\text { hospital mortality, } 2.72(1.23- \\
6.01) \text {, but not significantly in } \\
\text { multivariable analysis }\end{array}$ \\
\hline $\begin{array}{l}\text { Serum albumin } \\
\text { level }(g / d L)\end{array}$ & $\begin{array}{l}\text { Serum albumin }<2.6 \\
\text { independently } \\
\text { increased hospital } \\
\text { mortality, } 3.5(1.8-6.6)\end{array}$ & $\begin{array}{c}\text { Lower serum } \\
\text { albumin (per 1-g/dl } \\
\text { decrease) } \\
\text { independently } \\
\text { increased hospital } \\
\text { mortality, 2.08 (1.41- } \\
\text { 3.06) }\end{array}$ & - & - & No association & No association & - & $\begin{array}{l}\text { Lower serum albumin (per 1- } \\
\mathrm{g} / \mathrm{dl} \text { decrease) univariably } \\
\text { increased hospital mortality, } \\
1.69(1.04-2.74) \text {, but not } \\
\text { significantly in multivariable } \\
\text { analysis }\end{array}$ \\
\hline
\end{tabular}

Values are given as odds ratio (95\% confidence interval), unless otherwise indicated.

${ }^{a}$ HIV diagnosis within 60 days before ICU admission.

Diagnosis was based on identification of Pneumocystis in the sputum, bronchoalveolar-lavage fluid, or transbronchoscopic or surgical lung biopsy.

Values are given as hazard ratio (95\% confidence interval).

ART, antiretroviral therapy; HAART, highly active antiretroviral therapy. 
assess the adherence to antiretroviral therapy prescribed in those patients who had been on HAART prior to hospital admission, nor were we able to assess the bioavailability of HAART that was initiated and continued in those patients during the ICU stay.

\section{Conclusions}

In conclusion, we found respiratory failure remained the most common cause of ICU admission for HIV-infected patients in the era of HAART. The hospital mortality of HIV-infected patients who were admitted to the ICU was associated with low CD4 lymphocyte count and the diagnosis of sepsis.

\section{Key messages}

- Respiratory failure is the most common cause of ICU admission for HIV-infected patients in the era of HAART, followed by sepsis and neurological disease.

- The hospital mortality of HIV-infected patients who are admitted to the ICU is associated with low CD4 lymphocyte count and the diagnosis of sepsis.

- Low serum albumin level and delayed ICU admission are associated with poor outcome.

\begin{abstract}
Abbreviations
AOR: adjusted odds ratio; APACHE II: Acute Physiology and Chronic Health Evaluation II; Cl: confidence interval; CMV: cytomegalovirus; HAART: highly active antiretroviral therapy; HRCT: high-resolution computed tomography; IQR: interquartile range; SAPS II: Simplified Acute Physiology Score II; SOFA: Sequential Organ Failure Assessment.
\end{abstract}

\section{Acknowledgements}

This study was supported by the National Science Council (National Research Program for Biopharmaceuticals NSC 100-2325-B-002-057 to ChaoChi Ho) and Centers for Disease Control, Taiwan (AIDS-97-1002 to ChienChing Hung). This work was performed at the intensive care units of National Taiwan University Hospital, Taipei, Taiwan.

\section{Author details \\ 'Department of Internal Medicine, Far East Memorial Hospital, Nanya South Road, New Taipei City 220, Taiwan. ${ }^{2}$ Division of Infectious Diseases, Department of Internal Medicine, National Taiwan University Hospital, Chung-Shan South Road., Taipei 100, Taiwan. 'Division of Thoracic Surgery, Department of Surgery, National Taiwan University Hospital, Chung-Shan South Road., Taipei 100, Taiwan. ${ }^{4}$ Institute of Statistical Science, Academia Sinica, Academia Road Section 2, Taipei 115, Taiwan. ${ }^{5}$ Division of Chest Medicine, Department of Internal Medicine, National Taiwan University Hospital, Chung-Shan South Road, Taipei 100, Taiwan.}

\footnotetext{
Authors' contributions

HHC participated in the design of the study, collected data, performed the statistical analysis, and drafted the manuscript. $\mathrm{CCH}$ participated in the design of the study, analyzed and interpreted data, and revised the manuscript. CHL acquired surgical samples, and helped to collect data. HYC performed the statistical analysis, and helped to revise the manuscript. MYC, WHS, SMH, and HYS participated in clinical evaluation of patients, and helped to collect data. CCH conceived of the study, participated in its design and coordination, and revised the manuscript. CJY participated in the design and coordination of the study. All authors read and approved the final manuscript.
}

\section{Competing interests}

The authors declare that they have no competing interests.

Received: 12 April 2011 Revised: 21 July 2011

Accepted: 26 August 2011 Published: 26 August 2011

\section{References}

1. Huang L, Quartin A, Jones D, Havlir DV: Intensive care of patients with HIV infection. N Engl J Med 2006, 355:173-181.

2. Crothers K, Huang L, Goulet JL, Goetz MB, Brown ST, RodriguezBarradas MC, Oursler KK, Rimland D, Gibert CL, Butt AA, Justice AC: HIV infection and risk for incident pulmonary diseases in the combination antiretroviral therapy era. Am J Respir Crit Care Med 2011, 183:388-395.

3. Morris A, Masur H, Huang L: Current issues in critical care of the human immunodeficiency virus-infected patient. Crit Care Med 2006, 34:42-49.

4. Rosen MJ, Narasimhan M: Critical care of immunocompromised patients: human immunodeficiency virus. Crit Care Med 2006, 34(Suppl 9):245-250.

5. Rosenberg AL, Seneff MG, Atiyeh L, Wagner R, Bojanowski L, Zimmerman JE: The importance of bacterial sepsis in intensive care unit patients with acquired immunodeficiency syndrome: Implications for future care in the age of increasing antiretroviral resistance. Crit Care Med 2001, 29:548-556.

6. Gebo KA, Diener-West M, Moore RD: Hospitalization rates in an urban cohort after the introduction of highly active antiretroviral therapy. $J$ Acquir Immune Defic Syndr 2001, 27:143-152.

7. Afessa B, Green B: Clinical course, prognostic factors, and outcome prediction for HIV patients in the ICU. The PIP (Pulmonary complications, ICU support, and prognostic factors in hospitalized patients with HIV) study. Chest 2000, 118:138-145.

8. Morris A, Creasman J, Turner J, Luce JM, Wachter RM, Huang L: Intensive care of human immunodeficiency virus infected patients during the era of highly active antiretroviral therapy. Am J Respir Crit Care Med 2002, 166:262-267.

9. Narasimhan M, Posner AJ, DePalo VA, Mayo PH, Rosen MJ: Intensive care in patients with HIV infection in the era of highly active antiretroviral therapy. Chest 2004, 125:1800-1804.

10. Casalino E, Wolff M, Ravaud P, Choquet C, Bruneel F, Regnier B: Impact of HAART advent on admission patterns and survival in HIV-infected patients admitted to an intensive care unit. AIDS 2004, 18:1429-1433.

11. Nuesch R, Geigy N, Schaedler E, Battegay M: Effect of highly active antiretroviral therapy on hospitalization characteristics of HIV infected patients. Eur J Clin Microbiol Infect Dis 2002, 21:684-687.

12. Vincent B, Timsit JF, Auburtin M, Schortgen F, Bouadma L, Wolff M, Regnier B: Characteristics and outcomes of HIV-infected patients in the ICU: impact of the highly active antiretroviral treatment era. Intensive Care Med 2004, 30:859-866.

13. Zolopa A, Andersen J, Powderly W, Sanchez A, Sanne I, Suckow C, Hogg E, Komarow L: Early antiretroviral therapy reduces AIDS progression/death in individuals with acute opportunistic infections: a multicenter randomized strategy trial. PLOS One 2009, 4:e5575.

14. Vargas-Infante YA, Guerrero ML, Ruiz-Palacios GM, Soto-Ramírez LE, Del Río C, Carranza J, Domínguez-Cherit G, Sierra-Madero JG: Improving outcome of human immunodeficiency virus-infected patients in a Mexican intensive care unit. Arch Med Res 2007, 38:827-833.

15. Croda J, Croda MG, Neves A, De Sousa dos Santos S: Benefit of antiretroviral therapy on survival of human immunodeficiency virusinfected patients admitted to an intensive care unit. Crit Care Med 2009, 37:1605-1611.

16. Powell K, Davis JL, Morris AM, Chi A, Bensley MR, Huang L: Survival for patients with HIV admitted to the ICU continues to improve in the current era of combination antiretroviral therapy. Chest 2009, 135:11-17.

17. Barbier F, Coquet I, Legriel S, Pavie J, Darmon M, Mayaux J, Molina JM, Schlemmer B, Azoulay E: Etiologies and outcome of acute respiratory failure in HIV-infected patients. Intensive Care Med 2009, 35:1678-1686.

18. Coquet I, Pavie J, Palmer P, Barbier F, Legriel S, Mayaux J, Molina JM, Schlemmer B, Azoulay E: Survival trends in critically ill HIV-infected patients in the highly active antiretroviral therapy era. Crit Care 2010, 14: R107.

19. Japiassú AM, Amâncio RT, Mesquita EC, Medeiros DM, Bernal HB, Nunes EP, Luz PM, Grinsztejn B, Bozza FA: Sepsis is a major determinant of outcome in critically ill HIV/AIDS patients. Crit Care 2010, 14:R152. 
20. Khouli H, Afrasiabi A, Shibli M, Hajal R, Barrett CR, Homel P: Outcome of critically ill human immunodeficiency virus-infected patients in the era of highly active antiretroviral therapy. J Intensive Care Med 2005, 20:327-333.

21. Department of Health and Human Services Panel on Antiretroviral Guidelines for Adults and Adolescents, Office of AIDS Research Advisory Council: Guidelines for the use of antiretroviral agents in HIV-1-infected adults and adolescents. 2007 [http://www.aidsinfo.nih.gov/ContentFiles/ AdultandAdolescentGL.pdf].

22. Knaus WA, Draper EA, Wagner DP, Zimmerman JE: APACHE II: a severity of disease classification system. Crit Care Med 1985, 13:818-829.

23. Armbruster C, Pokieser L, Hassl A: Diagnosis of Pneumocystis carinii pneumonia by bronchoalveolar lavage in AIDS patients: comparison of Diff-Quik, fungifluor stain, direct immunofluorescence test and polymerase chain reaction. Acta Cytol 1995, 39:1089-1093.

24. Thomas CF Jr, Limper AH: Pneumocystis pneumonia. N Engl J Med 2004, 350:2487-2498.

25. Dickson SJ, Batson S, Copas AJ, Edwards SG, Singer M, Miller RF: Survival of HIV-infected patients in the intensive care unit in the era of highly active antiretroviral therapy. Thorax 2007, 62:964-968.

26. Hung CC, Hsiao CF, Chen MY, Hsieh SM, Chang SY, Sheng WH, Sun HY, Chang SC: Improved survival of persons with human immunodeficiency virus type 1 infection in the era of highly active antiretroviral therapy in Taiwan. Jpn J Infect Dis 2006, 59:222-228.

27. Sun HY, Chen MY, Hsieh SM, Sheng WH, Chang SY, Hsiao CF, Hung CC, Chang SC: Changes in the clinical spectrum of opportunistic illnesses in persons with HIV infection in Taiwan in the era of highly active antiretroviral therapy. Jpn J Infect Dis 2006, 59:311-316.

28. Timsit JF: Open the intensive care unit doors to HIV-infected patients with sepsis. Crit Care 2005, 9:629-630.

29. Mrus JM, Braun L, Yi MS, Linde-Zwirble WT, Johnston JA: Impact of HIV/ AIDS on care and outcomes of severe sepsis. Crit Care 2005, 9:R623-630.

30. Müller M, Wandel S, Colebunders R, Attia S, Furrer H, Egger M, leDEA Southern and Central Africa: Immune reconstitution inflammatory syndrome in patients starting antiretroviral therapy for HIV infection: a systematic review and meta-analysis. Lancet Infect Dis 2010, 10:251-261.

31. Wittkop L, Günthard HF, de Wolf F, Dunn D, Cozzi-Lepri A, de Luca A, Kücherer C, Obel N, von Wyl V, Masquelier B, Stephan C, Torti C, Antinori A, García F, Judd A, Porter K, Thiébaut R, Castro H, van Sighem Al, Colin C, Kjaer J, Lundgren JD, Paredes R, Pozniak A, Clotet B, Phillips A, Pillay D, Chêne G, The EuroCoord-CHAIN study group: Effect of transmitted drug resistance on virological and immunological response to initial combination antiretroviral therapy for HIV (EuroCoord-CHAIN joint project): a European multicohort study. Lancet Infect Dis 2011, 11:363-371.

32. Chang SY, Chen MY, Lee CN, Sun HY, Ko W, Chang SF, Chang KL, Hsieh SM, Sheng WH, Liu WC, Wu CH, Kao CL, Hung CC, Chang SC: Trends of antiretroviral drug resistance in treatment-naive patients with human immunodeficiency virus type 1 infection in Taiwan. J Antimicrob Chemother 2008, 61:689-693.

33. Yagi T, Kaneko T, Tsuruta R, Kasaoka S, Miyauchi T, Fujita M, Kawamura Y, Sakka SG, Maekawa T: Global end-diastolic volume, serum osmolarity, and albumin are risk factors for increased extravascular lung water. J Crit Care 2011, 26(2):224, e9-13.

34. Myburgh JA: The evidence for small-volume resuscitation with hyperoncotic albumin in critical illness. Crit Care 2008, 12:143.

\section{Submit your next manuscript to BioMed Central and take full advantage of:}

- Convenient online submission

- Thorough peer review

- No space constraints or color figure charges

- Immediate publication on acceptance

- Inclusion in PubMed, CAS, Scopus and Google Scholar

- Research which is freely available for redistribution

Submit your manuscript at www.biomedcentral.com/submit 